OPEN ACCESS

Edited by:

Kazuya Iwabuchi,

Kitasato University School of

Medicine, Japan

Reviewed by:

Vipin Kumar,

University of California, San Diego,

United States

Masaki Terabe,

National Cancer Institute (NIH),

United States

*Correspondence:

Akihiro Ishizu

aishizu@med.hokudai.ac.jp

Specialty section:

This article was submitted to T Cell Biology,

a section of the journal

Frontiers in Immunology

Received: 09 December 2017

Accepted: 05 March 2018

Published: 15 March 2018

Citation:

Nishioka Y, Masuda S, Tomaru U and Ishizu A (2018) CD1d-Restricted Type II NKT Cells Reactive With Endogenous Hydrophobic Peptides. Front. Immunol. 9:548. doi: 10.3389/fimmu.2018.00548

\section{CD1d-Restricted Type II NKT Cells Reactive With Endogenous Hydrophobic Peptides}

\author{
Yusuke Nishioka', Sakiko Masuda ${ }^{2}$, Utano Tomaru and Akihiro Ishizu ${ }^{2 *}$ \\ ${ }^{1}$ Graduate School of Health Sciences, Hokkaido University, Sapporo, Japan, ${ }^{2}$ Faculty of Health Sciences, Hokkaido \\ University, Sapporo, Japan, ${ }^{3}$ Department of Pathology, Faculty of Medicine, Graduate School of Medicine, Hokkaido \\ University, Sapporo, Japan
}

NKT cells belong to a distinct subset of $T$ cells that recognize hydrophobic antigens presented by major histocompatibility complex class I-like molecules, such as CD1d. Because NKT cells stimulated by antigens can activate or suppress other immunocompetent cells through an immediate production of a large amount of cytokines, they are regarded as immunological modulators. CD1d-restricted NKT cells are classified into two subsets, namely, type I and type II. CD1d-restricted type I NKT cells express invariant $\mathrm{T}$ cell receptors (TCRs) and react with lipid antigens, including the marine sponge-derived glycolipid $\alpha$-galactosylceramide. On the contrary, CD1d-restricted type II NKT cells recognize a wide variety of antigens, including glycolipids, phospholipids, and hydrophobic peptides, by their diverse TCRs. In this review, we focus particularly on CD1d-restricted type II NKT cells that recognize endogenous hydrophobic peptides presented by CD1d. Previous studies have demonstrated that CD1d-restricted type I NKT cells usually act as pro-inflammatory cells but sometimes behave as anti-inflammatory cells. It has been also demonstrated that CD1d-restricted type II NKT cells play opposite roles to CD1d-restricted type I NKT cells; thus, they function as anti-inflammatory or pro-inflammatory cells depending on the situation. In line with this, CD1d-restricted type II NKT cells that recognize type II collagen peptide have been demonstrated to act as anti-inflammatory cells in diverse inflammation-induction models in mice, whereas pro-inflammatory CD1d-restricted type II NKT cells reactive with sterol carrier protein 2 peptide have been demonstrated to be involved in the development of small vessel vasculitis in rats.

Keywords: CD1d, NKT cell, hydrophobic peptide, sulfatide, glycolipid

\section{INTRODUCTION}

NKT cells are first reported as T cells that share surface markers of NK cells and recognize antigens presented by the major histocompatibility complex (MHC) class I-like molecule CD1d (1). Because subsequent studies have demonstrated that there are CD1d-restricted $\mathrm{T}$ cells that do not express NK markers and that conventional T cells express NK markers when activated, CD1d restriction rather than the expression of NK markers is considered to be a critical feature of NKT cells $(2,3)$. Currently, NKT cells are defined as T cells that recognize antigens presented by MHC class I-like molecules, including CD1d. 
CD1d is a CD1 family member that can present hydrophobic antigens (e.g., glycolipids) (4). Whereas the CD1 family includes CD1a, CD1b, CD1c, CD1d, and CD1e in humans, rodents express only CD1d but not CD1a, CD1b, CD1c, and CD1e $(5,6)$.

CD1d-restricted NKT cells stimulated by antigens can activate or suppress other immunocompetent cells through an immediate production of a large amount of cytokines. Thus, these cells are regarded as immunological modulators. They are classified into two subsets, namely, type I and type II, according to the different usage of T-cell receptors (TCRs) $(7,8)$.

CD1d-restricted type I NKT cells are also called invariant NKT cells because of their usage of the limited $\alpha$-chain (V $\alpha 24-\mathrm{J} \alpha 18$ in humans and $\mathrm{V} \alpha 14-\mathrm{J} \alpha 18$ in rodents) with no or very few nucleotide insertions in the complementarity-determining region 3 that constitutes TCR. These cells can recognize a glycolipid, $\alpha$-galactosylceramide ( $\alpha$-GalCer) (9-11). Based on this evidence, $\alpha$-GalCer-loaded CD1d tetramers are employed to detect CD1drestricted type I NKT cells. Up to now, several microbial and endogenous lipids have been identified as antigens recognized by CD1d-restricted type I NKT cells (12).

On the contrary, CD1d-restricted type II NKT cells use diverse TCRs (13) and react with a wide variety of antigens, including microbial and endogenous glycolipids and phospholipids and endogenous hydrophobic peptides, but do not recognize $\alpha$-GalCer. Due to the difficulty in preparation of ligand-loaded CD1d tetramers to detect CD1d-restricted type II NKT cells specifically, studies on these cells fall behind those on CD1drestricted type I NKT cells. However, in terms of the abundance of CD1d-restricted type II NKT cells compared to CD1d-restricted type I NKT cells in humans, it is worthy of understanding their physiological and pathological roles $(14,15)$. In this review, we focus particularly on CD1d-restricted type II NKT cells that recognize endogenous hydrophobic peptides presented by CD1d.

\section{ANTIGENS RECOGNIZED BY CD1d- RESTRICTED TYPE II NKT CELLS}

Previous studies have demonstrated that CD1d-restricted type II NKT cells recognize microbial and endogenous glycolipids and phospholipids. Tatituri et al. identified Mycobacterium tuberculosis-derived phosphatidylglycerol (PG), diphosphatidylglycerol (cardiolipin), and phosphatidylinositol as exogenous antigens recognized by CD1d-restricted type II NKT cells (16). More recently, Wolf et al. have demonstrated that Gram-positive Listeria monocytogenes-derived PG is also recognized by CD1drestricted type II NKT cells (17). It has been demonstrated that CD1d-restricted type II NKT cells can recognize lysophosphatidylcholine species (18) and sulfatides, which are endogenous glycolipids abundant in the central nervous system (19). Nair et al. identified two types of CD1d-restricted type II NKT cells in patients with Gaucher's disease (20). These cells recognize $\beta$-glucosylceramide and glucosylsphingosine. Rhost et al. have demonstrated that $\beta$-GalCer is also recognized by CD1drestricted type II NKT cells (21).

Although CD1d mainly presents lipid antigens, such as glycolipids, earlier studies depicted that it can present hydrophobic peptides $(22,23)$. In 2011, Liu et al. reported that type II collagen peptide could be an autoantigen recognized by CD1d-restricted NKT cells (24). Although they did not declare the subtype of type II collagen-reactive CD1d-restricted NKT cells in the paper, it appears to be a type II phenotype in terms of the antigen property. More recently, our group demonstrated that the hydrophobic peptide derived from sterol carrier protein 2 (SCP2), an intracellular lipid transporter, could be presented by CD1d and then recognized by CD1d-restricted type II NKT cells (25). Girardi et al. conducted X-ray analyzes of binding formation of CD1d and peptide antigens (26). The results demonstrated that the binding mode of peptides and CD1d is obviously different from that of glycolipids and CD1d but rather resemble that of peptides and MHC.

Castano et al. reported that peptide antigens that contain a motif of [F/W]XX[I/L/M]XXW can bind to CD1d (22). However, neither type II collagen peptide PPGANGNPGPAGPPG (24) nor SCP2 peptide FFQGPLKITGNMGLA (25) contains this motif. Furthermore, the membrane proximal external region of HIV-1 glycoprotein 41 peptide that contains this motif cannot bind to CD1d (26). The collective findings suggest that it is not easy to generalize the motif that represents the binding potential to CD1d. Not only amino acid sequences but also electric charge and peptide length could influence the binding to CD1d.

\section{FUNCTION OF CD1d-RESTRICTED TYPE I NKT CELLS}

It has been demonstrated that the development of experimental autoimmune encephalomyelitis (EAE) and uveitis is enhanced in CD1d-restricted type I NKT cell-deficient J $\alpha 18$ knockout mice $(27,28)$. In addition, the activation of CD1d-restricted type I NKT cells protects non-obese diabetes (NOD) mice from developing insulitis (29). These findings suggest an anti-inflammatory aspect of CD1d-restricted type I NKT cells in these murine autoimmune diseases. On the contrary, Jahng et al. reported that the simultaneous activation of CD1d-restricted type I NKT cells and myelin-reactive $\mathrm{T}$ cells exacerbated the progression of EAE (30), and Griseri et al. reported that CD1d-restricted type I NKT cells accelerated insulitis in the CD8 T cell-mediated diabetes model (31). These controversial results might be attributed to the experimental conditions. Interestingly, it has been demonstrated that CD1d-restricted type I NKT cells protect from Th1-mediated inflammation (32-34) but exacerbate Th2-mediated inflammation (35-37).

The following studies suggest a rather pro-inflammatory than anti-inflammatory phenotype of CD1d-restricted type I NKT cells. Chiba et al. reported that CD1d-restricted type I NKT cell number was increased in arthritic joints in the collageninduced arthritis model (33). In another antibody-induced arthritis model, CD1d-restricted type I NKT cells augmented inflammation in the joints by suppressing the production of the anti-inflammatory transforming growth factor $\beta$ (TGF- $\beta$ ) (34). CD1d-restricted type I NKT cells accelerated inflammation also in cholangitis model (38). Furthermore, Kumar et al. reported that CD1d-restricted type I NKT cells acted as an inflammation 
promoter in liver injury by activating NK cells that kill hepatocytes through Fas/Fas ligand (FasL) interaction as well as by producing the pro-inflammatory cytokines (39-41). The more recent study demonstrated that the activation of CD1d-restricted type I NKT cells in the lungs by Francisella tularensis induced tularemia-like disease in mice (42).
In tumor immunity, CD1d-restricted type I NKT cells are also associated with the promotion of immune response against tumors (43). For instance, it has been demonstrated that the activation of CD1d-restricted type I NKT cells increased survival in mice bearing B16 melanoma $(44,45)$. Subsequent studies have revealed that a large amount of interferon- $\gamma$ released from

\section{A}
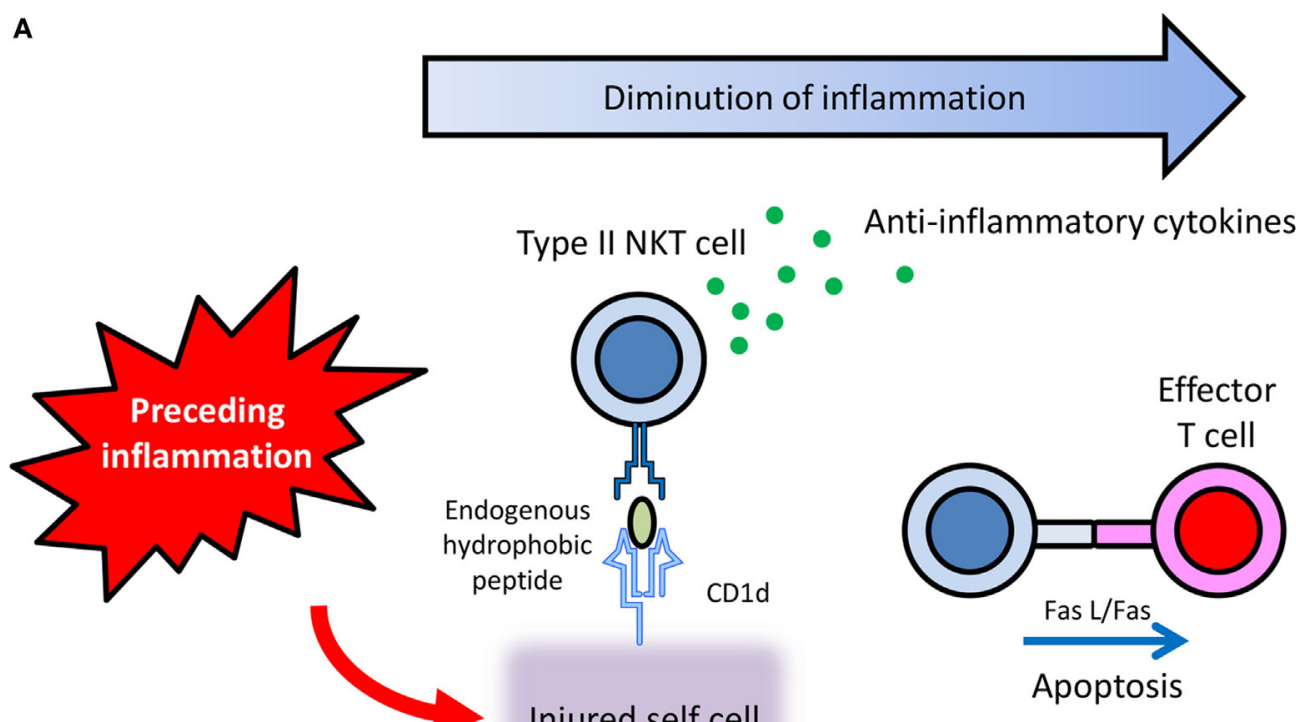

Injured self cell

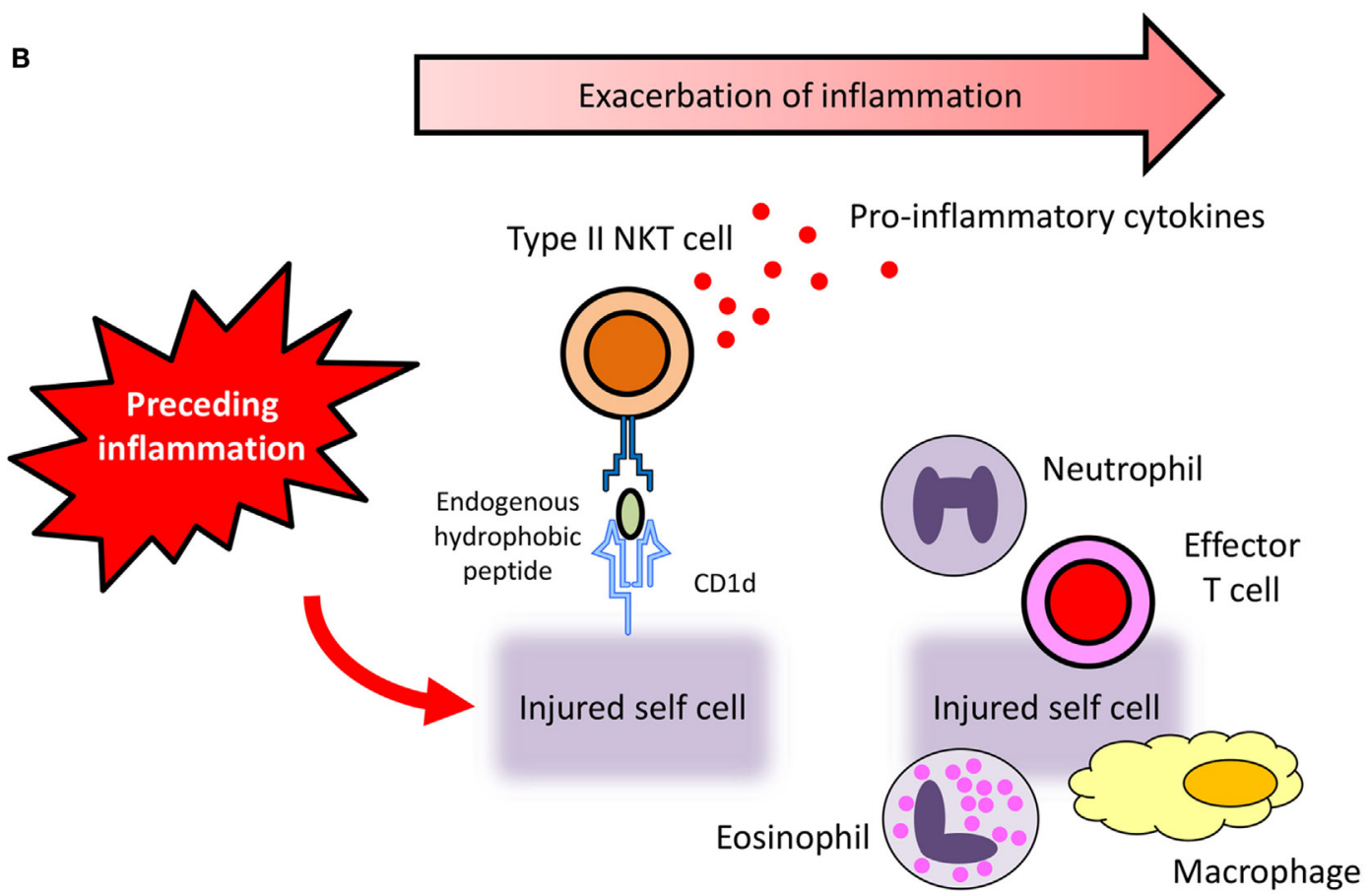

FIGURE 1 | Hypothetical diverse roles of CD1d-restricted type II NKT cells that recognize endogenous hydrophobic peptides. (A) Preceding inflammation sometimes results in the injury of own tissues. Under such situation, injured cells then present hydrophobic autoantigens, probably peptides, on their CD1d to activate CD1d-restricted type II NKT cells. Thereafter, activated CD1d-restricted type II NKT cells function to diminish inflammation by producing anti-inflammatory cytokines and by inducing apoptosis of effector cells via Fas/FasL interaction. (B) When CD1d-restricted type II NKT cells activated by endogenous hydrophobic peptides produce pro-inflammatory cytokines, the inflammation is exacerbated. 
activated CD1d-restricted type I NKT cells is pivotal for tumor protection $(46,47)$.

\section{FUNCTION OF CD1d-RESTRICTED TYPE II NKT CELLS}

The function of CD1d-restricted type II NKT cells has been investigated mainly by the following methods: (1) in vivo and/or in vitro stimulation by sulfatides; (2) observation of the difference in phenotype between CD1d knockout mice, which lack whole CD1d-restricted NKT cells, and Ja18 knockout mice, which solely lack CD1d-restricted type I NKT cells; and (3) use of $24 \alpha \beta$ transgenic mice that carry the CD1d-restricted type II NKT cellderived TCR gene. The stimulation of CD1d-restricted type II NKT cells by sulfatides resulted in anti-inflammatory effects on liver injury $(39,40)$. Kwiecinski et al. demonstrated that sulfatidestimulated CD1d-restricted type II NKT cells attenuated sepsis induced by Staphylococcus aureus (48). Concerning these mechanisms, some studies have demonstrated that sulfatide-stimulated CD1d-restricted type II NKT cells suppressed the activation of pro-inflammatory type I NKT cells $(39,49,50)$.

Terabe et al. and Renukaradhya et al. independently conducted experiments employing CD1d knockout and Ja18 knockout mice, and they both demonstrated that CD1d-restricted type II NKT cells downregulated cancer immunosurveillance $(51,52)$. Furthermore, other experiments that employed CD1d knockout and Jo18 knockout mice revealed that CD1d-restricted type II NKT cells attenuated the development of graft-versus-host disease after bone marrow transplantation (53).

Cardell et al. generated the CD1d-restricted type II NKT cell hybridoma VIII24 from MHC class II knockout mice (54). Skold et al. developed $24 \alpha \beta$ mice that carried the V $\alpha 3.2-\mathrm{V} \beta 9$ gene derived from the TCR of VIII24 hybridoma (55). Duarte et al. transduced the $\mathrm{V} \alpha 3.2-\mathrm{V} \beta 9$ gene into NOD mice and established $24 \alpha \beta / \mathrm{NOD}$ mice (56). These mice exhibited a decrease in the incidence of diabetes compared to the parent NOD mice. Furthermore, Liao et al. generated $24 \alpha \beta / C D 1 d T g$ mice that overexpressed CD1d, and demonstrated that these mice spontaneously developed colitis underlying dysregulated differentiation of CD1d-restricted $\mathrm{V} \alpha 3.2-\mathrm{V} \beta 9^{+}$type II NKT cells in the thymus (57).

The study published by Liu et al. (24) is noteworthy. They reported that type II collagen peptide-reactive CD1d-restricted NKT cells suppressed autoimmune arthritis by producing TGF- $\beta$, an anti-inflammatory cytokine, and by inducing apoptosis of effector cells through Fas/FasL interaction. This report encouraged us to make the following hypothesis: preceding inflammation sometimes results in the injury of own tissues. Under such situation, injured cells then present hydrophobic autoantigens, probably peptides, on their CD1d to activate CD1d-restricted type II NKT cells. Thereafter, activated CD1d-restricted type II NKT cells function to diminish inflammation by producing antiinflammatory cytokines and by inducing apoptosis of effector cells via Fas/FasL interaction (Figure 1A).

\section{INVOLVEMENT OF CD1d-RESTRICTED TYPE II NKT CELLS IN IMMUNE-RELATED INFLAMMATORY DISEASES}

It has been demonstrated that CD1d-restricted type II NKT cells play critical roles in the development of liver injury in an acute hepatitis B transgenic murine model (58). In addition, the activation of CD1d-restricted type II NKT cells is accompanied by conventional $\mathrm{T}$ cell activation and proinflammatory cytokine production, leading to an enhancement of hepatic injury in murine autoimmune hepatitis models (59).

In patients with ulcerative colitis (UC), sulfatide-reactive CD1d-restricted type II NKT cells in lamina propria mononuclear cells are increased compared to healthy controls and patients with Crohn's disease (60). Moreover, sulfatide stimulation induced pathogenic interleukin (IL)-13 production and IL-13R $\alpha 2$ expression on CD1d-restricted type II NKT cells from UC patients but not from healthy controls or patients with Crohn's disease. These findings are consistent with the previous report indicating that CD1d-restricted type II NKT cells with dysregulated differentiation is pathogenic in the murine colitis model (57). A recent study using CD1d-deficient (CD1d knockout) and CD1d-restricted type I NKT cell-deficient (J $\alpha 18$ knockout) mice has also demonstrated that pro-inflammatory type II NKT cells are involved in dextran sulfate sodium-induced colitis in mice (61).

More recently, our group has revealed the involvement of proinflammatory type II NKT cells that are reactive with the endogenous SCP2 peptide in the pathogenesis of small vessel vasculitis in rats $(25,62)$ (Figure 1B). CD1d-restricted type II NKT cells activated by the SCP2 peptide function to enhance inflammation by producing pro-inflammatory cytokines. Although further studies are needed to clarify the precise mechanism, the involvement of pro-inflammatory CD1d-restricted type II NKT cells that recognize endogenous hydrophobic peptide is worthy of attention in the pathogenesis of immune-related inflammatory diseases.

\section{AUTHOR CONTRIBUTIONS}

All authors listed have made a substantial, direct, and intellectual contribution to the work and approved it for publication.

\section{FUNDING}

This study was supported by a Grant-in-Aid from the Ministry of Education, Culture, Sports, Science and Technology of Japan with grant number 26293082 (AI), a grant from the Japan Research Committee of the Ministry of Health, Labor, and Welfare for Intractable Vasculitis (AI), and a grant from the Japan Agency for Medical Research and Development with grant number 15ek0109121 (AI). 


\section{REFERENCES}

1. Taniguchi M, Harada M, Kojo S, Nakayama T, Wakao H. The regulatory role of Vo14 NKT cells in innate and acquired immune response. Annu Rev Immunol (2003) 21:483-513. doi:10.1146/annurev.immunol.21.120601.141057

2. Godfrey DI, MacDonald HR, Kronenberg M, Smyth MJ, Van Kaer L. NKT cells: what's in a name? Nat Rev Immunol (2004) 4(3):231-7. doi:10.1038/nri1309

3. Bendelac A, Savage PB, Teyton L. The biology of NKT cells. Annu Rev Immunol (2007) 25:297-336. doi:10.1146/annurev.immunol.25.022106.141711

4. Rossjohn J, Pellicci DG, Patel O, Gapin L, Godfrey DI. Recognition of CD1d-restricted antigens by natural killer T cells. Nat Rev Immunol (2012) 12(12):845-57. doi:10.1038/nri3328

5. Reinink P, Van Rhijn I. Mammalian CD1 and MR1 genes. Immunogenetics (2016) 68(8):515-23. doi:10.1007/s00251-016-0926-x

6. Mori L, Lepore M, De Libero G. The immunology of CD1- and MR1restricted T cells. Annu Rev Immunol (2016) 34:479-510. doi:10.1146/ annurev-immunol-032414-112008

7. Godfrey DI, Stankovic S, Baxter AG. Raising the NKT cell family. Nat Immunol (2010) 11(3):197-206. doi:10.1038/ni.1841

8. Bandyopadhyay K, Marrero I, Kumar V. NKT cell subsets as key participants in liver physiology and pathology. Cell Mol Immunol (2016) 13(3):337-46. doi:10.1038/cmi.2015.115

9. Kawano T, Cui J, Koezuka Y, Toura I, Kaneko Y, Motoki K, et al. CD1drestricted and TCR-mediated activation of V $\alpha 14$ NKT cells by glycosylceramides. Science (1997) 278(5343):1626-9. doi:10.1126/science.278.5343.1626

10. Benlagha K, Weiss A, Beavis A, Teyton L, Bendelac A. In vivo identification of glycolipid antigen-specific T cells using fluorescent CD1d tetramers. J Exp Med (2000) 191(11):1895-903. doi:10.1084/jem.191.11.1895

11. Kita H, Naidenko OV, Kronenberg M, Ansari AA, Rogers P, He XS, et al. Quantitation and phenotypic analysis of natural killer $\mathrm{T}$ cells in primary biliary cirrhosis using a human CD1d tetramer. Gastroenterology (2002) 123(4):1031-43. doi:10.1053/gast.2002.36020

12. Kohlgruber AC, Donado CA, LaMarche NM, Brenner MB, Brennan PJ. Activation strategies for invariant natural killer T cells. Immunogenetics (2016) 68(8):649-63. doi:10.1007/s00251-016-0944-8

13. Marrero I, Ware R, Kumar V. Type II NKT cells in inflammation, autoimmunity, microbial immunity, and cancer. Front Immunol (2015) 6:316. doi:10.3389/fimmu.2015.00316

14. Dasgupta S, Kumar V. Type II NKT cells: a distinct CD1d-restricted immune regulatory NKT cell subset. Immunogenetics (2016) 68(8):665-76. doi:10.1007/ s00251-016-0930-1

15. Dhodapkar MV, Kumar V. Type II NKT cells and their emerging role in health and disease. J Immunol (2017) 198(3):1015-21. doi:10.4049/ jimmunol.1601399

16. Tatituri RV, Watts GF, Bhowruth V, Barton N, Rothchild A, Hsu FF, et al. Recognition of microbial and mammalian phospholipid antigens by NKT cells with diverse TCRs. Proc Natl Acad Sci US A (2013) 110(5):1827-32. doi:10.1073/pnas.1220601110

17. Wolf BJ, Tatituri RV, Almeida CF, Le Nours J, Bhowruth V, Johnson D, et al. Identification of a potent microbial lipid antigen for diverse NKT cells. J Immunol (2015) 195(6):2540-51. doi:10.4049/jimmunol.1501019

18. Chang DH, Deng H, Matthews P, Krasovsky J, Ragupathi G, Spisek R, et al. Inflammation-associated lysophospholipids as ligands for CD1d-restricted $\mathrm{T}$ cells in human cancer. Blood (2008) 112(4):1308-16. doi:10.1182/ blood-2008-04-149831

19. Jahng A, Maricic I, Aguilera C, Cardell S, Halder RC, Kumar V. Prevention of autoimmunity by targeting a distinct, noninvariant CD1d-reactive T cell population reactive to sulfatide. J Exp Med (2004) 199(7):947-57. doi:10.1084/ jem.20031389

20. Nair S, Boddupalli CS, Verma R, Liu J, Yang R, Pastores GM, et al. Type II NKT-TFH cells against Gaucher lipids regulate B-cell immunity and inflammation. Blood (2015) 125(8):1256-71. doi:10.1182/blood-2014-09-600270

21. Rhost S, Lofbom L, Rynmark BM, Pei B, Mansson JE, Teneberg S, et al. Identification of novel glycolipid ligands activating a sulfatide-reactive, CD1d-restricted, type II natural killer T lymphocyte. Eur J Immunol (2012) 42(11):2851-60. doi:10.1002/eji.201142350

22. Castano AR, Tangri S, Miller JE, Holcombe HR, Jackson MR, Huse WD, et al. Peptide binding and presentation by mouse CD1. Science (1995) 269(5221):223-6. doi:10.1126/science.7542403
23. Zeng Z, Castano AR, Segelke BW, Stura EA, Peterson PA, Wilson IA. Crystal structure of mouse CD1: an MHC-like fold with a large hydrophobic binding groove. Science (1997) 277(5324):339-45. doi:10.1126/science.277. 5324.339

24. Liu Y, Teige A, Mondoc E, Ibrahim S, Holmdahl R, Issazadeh-Navikas S. Endogenous collagen peptide activation of CD1d-restricted NKT cells ameliorates tissue-specific inflammation in mice. J Clin Invest (2011) 121(1):249-64. doi:10.1172/JCI43964

25. Nishioka Y, Yamaguchi M, Kawakami A, Munehiro M, Masuda S, Tomaru U, et al. Type II natural killer $\mathrm{T}$ cells that recognize sterol carrier protein 2 are implicated in vascular inflammation in the rat model of systemic connective tissue diseases. Am J Pathol (2017) 187(1):176-86. doi:10.1016/ j.ajpath.2016.09.014

26. Girardi E, Wang J, Zajonc DM. Structure of an $\alpha$-helical peptide and lipopeptide bound to the nonclassical major histocompatibility complex (MHC) class I molecule CD1d. J Biol Chem (2016) 291(20):10677-83. doi:10.1074/ jbc.M115.702118

27. Oh SJ, Chung DH. Invariant NKT cells producing IL- 4 or IL-10, but not IFN- $\gamma$, inhibit the Th1 response in experimental autoimmune encephalomyelitis, whereas none of these cells inhibits the Th17 response. J Immunol (2011) 186(12):6815-21. doi:10.4049/jimmunol.1003916

28. Oh K, Byoun OJ, Ham DI, Kim YS, Lee DS. Invariant NKT cells regulate experimental autoimmune uveitis through inhibition of Th17 differentiation. Eur J Immunol (2011) 41(2):392-402. doi:10.1002/eji.201040569

29. Naumov YN, Bahjat KS, Gausling R, Abraham R, Exley MA, Koezuka Y, et al. Activation of CD1d-restricted T cells protects NOD mice from developing diabetes by regulating dendritic cell subsets. Proc Natl Acad Sci U S A (2001) 98(24):13838-43. doi:10.1073/pnas.251531798

30. Jahng AW, Maricic I, Pedersen B, Burdin N, Naidenko O, Kronenberg M, et al. Activation of natural killer T cells potentiates or prevents experimental autoimmune encephalomyelitis. J Exp Med (2001) 194(12):1789-99. doi:10.1084/ jem.194.12.1789

31. Griseri T, Beaudoin L, Novak J, Mars LT, Lepault F, Liblau R, et al. Invariant NKT cells exacerbate type 1 diabetes induced by CD8 T cells. J Immunol (2005) 175(4):2091-101. doi:10.4049/jimmunol.175.4.2091

32. Saubermann LJ, Beck P, De Jong YP, Pitman RS, Ryan MS, Kim HS, et al. Activation of natural killer $\mathrm{T}$ cells by $\alpha$-galactosylceramide in the presence of CD1d provides protection against colitis in mice. Gastroenterology (2000) 119(1):119-28. doi:10.1053/gast.2000.9114

33. Chiba A, Kaieda S, Oki S, Yamamura T, Miyake S. The involvement of V $\alpha 14$ natural killer T cells in the pathogenesis of arthritis in murine models. Arthritis Rheum (2005) 52(6):1941-8. doi:10.1002/art.21056

34. Kim HY, Kim HJ, Min HS, Kim S, Park WS, Park SH, et al. NKT cells promote antibody-induced joint inflammation by suppressing transforming growth factor $\beta 1$ production. J Exp Med (2005) 201(1):41-7. doi:10.1084/ jem.20041400

35. Akbari O, Stock P, Meyer E, Kronenberg M, Sidobre S, Nakayama T, et al. Essential role of NKT cells producing IL-4 and IL-13 in the development of allergen-induced airway hyperreactivity. Nat Med (2003) 9(5):582-8. doi:10.1038/nm851

36. Wingender G, Rogers P, Batzer G, Lee MS, Bai D, Pei B, et al. Invariant NKT cells are required for airway inflammation induced by environmental antigens. J Exp Med (2011) 208(6):1151-62. doi:10.1084/jem.20102229

37. Nie H, Yang Q, Zhang G, Wang A, He Q, Liu M, et al. Invariant NKT cells act as an adjuvant to enhance Th2 inflammatory response in an OVA-induced mouse model of asthma. PLoS One (2015) 10(4):e0119901. doi:10.1371/ journal.pone.0119901

38. Wu SJ, Yang YH, Tsuneyama K, Leung PS, Illarionov P, Gershwin ME, et al. Innate immunity and primary biliary cirrhosis: activated invariant natural killer T cells exacerbate murine autoimmune cholangitis and fibrosis. Hepatology (2011) 53(3):915-25. doi:10.1002/hep.24113

39. Halder RC, Aguilera C, Maricic I, Kumar V. Type II NKT cell-mediated anergy induction in type I NKT cells prevents inflammatory liver disease. J Clin Invest (2007) 117(8):2302-12. doi:10.1172/JCI31602

40. Arrenberg P, Maricic I, Kumar V. Sulfatide-mediated activation of type II natural killer $\mathrm{T}$ cells prevents hepatic ischemic reperfusion injury in mice. Gastroenterology (2011) 140(2):646-55. doi:10.1053/j.gastro.2010.10.003

41. Kumar V. NKT-cell subsets: promoters and protectors in inflammatory liver disease. J Hepatol (2013) 59(3):618-20. doi:10.1016/j.jhep.2013.02.032 
42. Hill TM, Gilchuk P, Cicek BB, Osina MA, Boyd KL, Durrant DM, et al. Border patrol gone awry: lung NKT cell activation by Francisella tularensis exacerbates tularemia-like disease. PLoS Pathog (2015) 11(6):e1004975. doi:10.1371/ journal.ppat.1004975

43. Robertson FC, Berzofsky JA, Terabe M. NKT cell networks in the regulation of tumor immunity. Front Immunol (2014) 5:543. doi:10.3389/fimmu.2014. 00543

44. Kobayashi E, Motoki K, Uchida T, Fukushima H, Koezuka Y. KRN7000, a novel immunomodulator, and its antitumor activities. Oncol Res (1995) 7(10-11):529-34

45. Kawano T, Cui J, Koezuka Y, Toura I, Kaneko Y, Sato H, et al. Natural killer-like nonspecific tumor cell lysis mediated by specific ligand-activated Vo14 NKT cells. Proc Natl Acad Sci U S A (1998) 95(10):5690-3. doi:10.1073/ pnas.95.10.5690

46. Street SE, Cretney E, Smyth MJ. Perforin and interferon- $\gamma$ activities independently control tumor initiation, growth, and metastasis. Blood (2001) 97(1):192-7. doi:10.1182/blood.V97.1.192

47. Gonzalez-Aseguinolaza G, Van Kaer L, Bergmann CC, Wilson JM, Schmieg J, Kronenberg $\mathrm{M}$, et al. Natural killer $\mathrm{T}$ cell ligand $\alpha$-galactosylceramide enhances protective immunity induced by malaria vaccines. J Exp Med (2002) 195(5):617-24. doi:10.1084/jem.20011889

48. Kwiecinski J, Rhost S, Lofbom L, Blomqvist M, Mansson JE, Cardell SL, et al. Sulfatide attenuates experimental Staphylococcus aureus sepsis through a CD1d-dependent pathway. Infect Immun (2013) 81(4):1114-20. doi:10.1128/ IAI.01334-12

49. Zhang G, Nie H, Yang J, Ding X, Huang Y, Yu H, et al. Sulfatide-activated type II NKT cells prevent allergic airway inflammation by inhibiting type I NKT cell function in a mouse model of asthma. Am J Physiol Lung Cell Mol Physiol (2011) 301(6):L975-84. doi:10.1152/ajplung.00114.2011

50. Maricic I, Halder R, Bischof F, Kumar V. Dendritic cells and anergic type I NKT cells play a crucial role in sulfatide-mediated immune regulation in experimental autoimmune encephalomyelitis. J Immunol (2014) 193(3):103546. doi:10.4049/jimmunol.1302898

51. Terabe M, Swann J, Ambrosino E, Sinha P, Takaku S, Hayakawa Y, et al. A nonclassical non-V $\alpha 14 \mathrm{~J} \alpha 18 \mathrm{CD} 1 \mathrm{~d}$-restricted (type II) NKT cell is sufficient for down-regulation of tumor immunosurveillance. JExp Med (2005) 202(12):1627-33. doi:10.1084/jem.20051381

52. Renukaradhya GJ, Khan MA, Vieira M, Du W, Gervay-Hague J, Brutkiewicz RR. Type I NKT cells protect (and type II NKT cells suppress) the host's innate antitumor immune response to a B-cell lymphoma. Blood (2008) 111(12):5637-45. doi:10.1182/blood-2007-05-092866

53. Kim JH, Choi EY, Chung DH. Donor bone marrow type II (non-V $\alpha 14$ J $\alpha 18$ CD1d-restricted) NKT cells suppress graft-versus-host disease by producing IFN- $\gamma$ and IL-4. J Immunol (2007) 179(10):6579-87. doi:10.4049/ jimmunol.179.10.6579
54. Cardell S, Tangri S, Chan S, Kronenberg M, Benoist C, Mathis D. CD1restricted $\mathrm{CD}^{+} \mathrm{T}$ cells in major histocompatibility complex class II-deficient mice. J Exp Med (1995) 182(4):993-1004. doi:10.1084/jem.182.4.993

55. Skold M, Faizunnessa NN, Wang CR, Cardell S. CD1d-specific NK1.1 ${ }^{+}$T cells with a transgenic variant TCR. J Immunol (2000) 165(1):168-74. doi:10.4049/ jimmunol.165.1.168

56. Duarte N, Stenstrom M, Campino S, Bergman ML, Lundholm M, Holmberg $\mathrm{D}$, et al. Prevention of diabetes in nonobese diabetic mice mediated by CD1d-restricted nonclassical NKT cells. J Immunol (2004) 173(5):3112-8. doi:10.4049/jimmunol.173.5.3112

57. Liao CM, Zimmer MI, Shanmuganad S, Yu HT, Cardell SL, Wang CR. Dysregulation of CD1d-restricted type II natural killer T cells leads to spontaneous development of colitis in mice. Gastroenterology (2012) 142(2):e1-2. doi:10.1053/j.gastro.2011.10.030

58. Baron JL, Gardiner L, Nishimura S, Shinkai K, Locksley R, Ganem D. Activation of a nonclassical NKT cell subset in a transgenic mouse model of hepatitis B virus infection. Immunity (2002) 16(4):583-94. doi:10.1016/ S1074-7613(02)00305-9

59. Weng X, He Y, Visvabharathy L, Liao CM, Tan X, Balakumar A, et al. Crosstalk between type II NKT cells and T cells leads to spontaneous chronic inflammatory liver disease. J Hepatol (2017) 67(4):791-800. doi:10.1016/j. jhep.2017.05.024

60. Fuss IJ, Joshi B, Yang Z, Degheidy H, Fichtner-Feigl S, de Souza H, et al. IL-13R $\alpha 2$-bearing, type II NKT cells reactive to sulfatide self-antigen populate the mucosa of ulcerative colitis. Gut (2014) 63(11):1728-36. doi:10.1136/ gutjnl-2013-305671

61. Sagami S, Ueno Y, Tanaka S, Fujita A, Niitsu H, Hayashi R, et al. Choline deficiency causes colonic type II natural killer T (NKT) cell loss and alleviates murine colitis under type I NKT cell deficiency. PLoS One (2017) 12(1):e0169681. doi:10.1371/journal.pone.0169681

62. Iinuma C, Waki M, Kawakami A, Yamaguchi M, Tomaru U, Sasaki N, et al. Establishment of a vascular endothelial cell-reactive type II NKT cell clone from a rat model of autoimmune vasculitis. Int Immunol (2015) 27(2):105-14. doi:10.1093/intimm/dxu088

Conflict of Interest Statement: The authors declare that the research was conducted in the absence of any commercial or financial relationships that could be construed as a potential conflict of interest.

Copyright (c) 2018 Nishioka, Masuda, Tomaru and Ishizu. This is an open-access article distributed under the terms of the Creative Commons Attribution License (CC $B Y)$. The use, distribution or reproduction in other forums is permitted, provided the original author(s) and the copyright owner are credited and that the original publication in this journal is cited, in accordance with accepted academic practice. No use, distribution or reproduction is permitted which does not comply with these terms. 